\title{
In vitro culture of embryonic disc cells from porcine blastocysts
}

\author{
MT Hochereau-de Reviers, C Perreau
}

\begin{abstract}
URA INRA-CNRS, 1291 Physiologie de la Reproduction des Mammifères Domestiques, 37380 Nouzilly, France
\end{abstract}

(5th Franco-Czechoslovak Meeting, Jouy-en-Josas, December 1992)

\begin{abstract}
Summary - The aim of the present study was to define the conditions of preparation and in vitro culture of embryonic discs allowing proliferation of ES-like cells. G5-6 porcine blastocysts (G0 = day of $\mathrm{Al}$ ) were cultured in toto; in $\mathrm{G10-11}$ blastocysts, trophectoderm and primitive endoderm were microsurgically removed from embryonic discs (ED) which were cultured either on plastic or on a feeder layer. Feeder cells were foetal G30 porcine fibroblasts which had been previously irradiated. Culture medium was DMEM supplemented with $0.1 \mathrm{mM} \beta$-mercaptoethanol, $5 \%$ foetal calf serum, $5 \%$ Ultroser $\mathrm{G}$ and $10^{3} \mathrm{IU} \mathrm{LIF}$; cultures were performed at $38^{\circ} \mathrm{C}$. Colonies were reseeded weekly. Few embryonic discs from G5-6 and no elongating blastocysts gave rise to ES-like cells. At least $50 \%$ G10-11 ED attached and developed multilayered colonies (100 cells) of small ovoid ES-like cells. Colonies from 4 sows were maintained in culture for at least $8 \mathrm{wk}$. Addition of PDGF, insulin or both, induced a transitory stimulation of growth in G6 or G10-11 ED; TGF $\beta$ did not modify growth of G6 ICM. Uterine G10-11 flushing medium or retinol induced differentiation of ES-like cells. These cells introduced in nude mice induced teratoma.
\end{abstract}

pig / embryo / embryonic disc / culture conditions / teratoma

Résumé - Culture in vitro des cellules du disque embryonnaire issues de blastocystes de porc. Le but de ce travail était de définir les conditions d'isolement et de culture in vitro des cellules du bouton embryonnaire, qui permettent la prolifération de cellules souches embryonnaires. Des blastocystes entiers (G5-6 de gestation ; Go : jour de l'insémination) ou des disques embryonnaires isolés ont été mis en culture. Les disques embryonnaires (G10-11) ont été isolés par microdissection et élimination du trophectoderme et de l'endoderme primitif. Les cultures ont été faites sur plastique ou sur une couche de fibroblastes porcins foetaux (G30) irradiés. On a utilisé comme milieu de culture, du DMEM supplémenté avec 0,1 $\mathrm{mM} \beta$-mercaptoéthanol, $5 \%$ de sérum de veau fœtal, $5 \%$ $d^{\prime} U$ ltroser $\mathrm{G}$ et $10^{3} \mathrm{UI} \mathrm{LIF}$, à $38^{\circ} \mathrm{C}$. Les colonies ont été repiquées chaque semaine. Peu de cellules souches embryonnaires sont isolées à partir d'embryons G5-6 et aucune après le début de l'allongement des blastocystes. Au moins 50\% des disques embryonnaires G10-11 forment des colonies de petites cellules ovoïdes (100 ou plus). Des colonies issues de 4 truies ont pu être conservées au moins 8 semaines sans se différencier. L'addition de PDGF, d'insuline ou des 2 augmente transitoirement la croissance des colonies issues de blastocystes G10-11 ou G6; celle de TGF $\beta$ est inefficace sur la croissance des colonies issues de blastocystes G5-6. L'addition de milieu utérin (G1011) ou de rétinol induit la différenciation des cellules du disque embryonnaire en des types cellulaires variés. Après leur introduction dans des souris Nude, ces colonies donnent des tératomes. 


\section{INTRODUCTION}

The inner cell mass appears at the time of blastocoele organization in the embryo; it is formed from totipotent cells which originate from the different cell lineages of the embryo. These in vitro cell cultures might give rise to embryonic stem cell (ES) lines. Such cells contribute to the formation of the different tissues and organs including the germ line after introduction into host blastocysts, thereby producing chimaeras (Evans and Kaufman, 1981; Martin, 1981). This method has been well developed in mice (Lallemand and Brulet, 1990), but no such ES lines deriving from ICM or embryonic disc and producing chimaera have been obtained in farm animals (Yang and Anderson, 1992). However, embryoderived cells with differentiation potentialities have been isolated from porcine embryos (Notarianni et al, 1990; Piedrahita et al, 1990; Strojek et al, 1990; MeineckeTillmann and Meinecke, 1991; Wilmut et al, 1991).

The aim of the present study was to define the conditions for the isolation of embryonic discs (ED) from porcine embryos, for the maintenance of in vitro cultures of these porcine ED and to select the culture conditions allowing proliferation of ES-like cells.

\section{MATERIAL AND METHODS}

\begin{abstract}
Animals
Seventy cyclic gilts aged 5 months (Meishan: Mei) or 7-9 months (Large White: LW or West Hybrid: $W H$ ) were used. They received an oral Regumate (Roussel-UCLAF) treatment $(20 \mathrm{mg} /$ d) for a period of $18 \mathrm{~d}$ and oestrus activity was observed daily for 5 to $6 \mathrm{~d}$ after the end of treatment. The gilts were inseminated $\left(6 \times 10^{9}\right.$ spermatozoa) twice, the first day of oestrus (GO of pregnancy) and $24 \mathrm{~h}$ later with Large White spermatozoa.
\end{abstract}

\section{Embryonic disc preparation}

Blastocysts were collected by flushing oviduct and uterine horns with sterile flushing medium (PBS supplemented with $10 \%$ fœtal calf serum FCS) at $38^{\circ} \mathrm{C}$. Young G5-6 blastocysts were cultured in toto. Embryonic discs of G10-11 blastocysts were microsurgically dissected with scissors; trophectoderm and primitive endoderm were removed mechanically from embryonic discs (fig 1a). They were cultured either directly or on a monolayer of feeder cells, in $1.9 \mathrm{~cm}^{2} \mathrm{cul}-$ ture wells previously coated with collagen I. Two to 3 blastocysts or ED were placed in each well.

\section{Feeder cell preparation}

Feeder cells were foetal fibroblasts from G30 porcine foetuses from which head, liver and

Fig 1. a. Embryonic disc (ED) microsurgically dissected from a round blastocyst originating from a pregnant LW sow at G11 of gestation. Few endoderm $(E)$ and trophectoderm $(T)$ cells were still present at the periphery of embryonic disc (x 200). b: Monolayer of cells from an embryonic disc originating from a G11 LW sow (3rd passage). The ED was cultured without feeder cells and gave rise to large ES-like epithelioid cells (ES e) $(x+00)$. c: Multilayered colony of ES-like cells (ES) from an embryonic disc of a G11 LW sow; ES-like cells appeared dark and the cell limits were not visible (3rd passage). The colony was cultured on a feeder monolayer of irradiated fibroblasts $(F)(x 1000)$. d: Teratoma observed in the dermal muscle of mouse 2, $18 \mathrm{~d}$ after injection of $10^{3}$ ES-like cells (3rd passage). The teratoma was delineated by layers of fibroblasts $(F)$. From the periphery to the centre of the teratoma, muscies (M), few cartilage cells (C), haematopoietic cells (B) with one megacaryocyte $(\mathrm{me})$ were present $(x 500)$. 

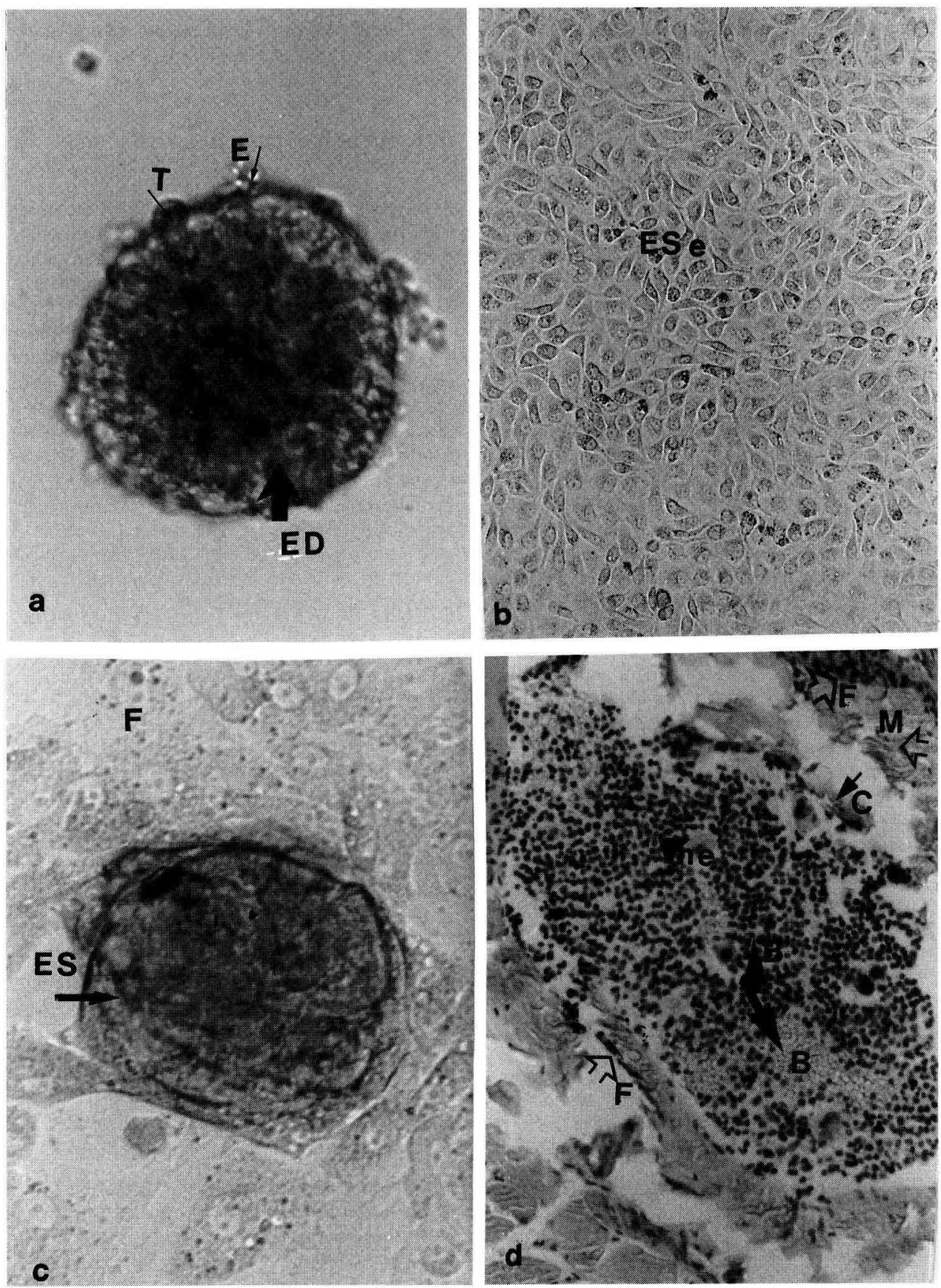
viscerae had been discarded. The foetuses were cut in small pieces mechanically and trypsinized (Trypsin T 8253 Sigma $2.5 \%$ + Dnase Sigma $0.01 \%$ in $\mathrm{Ca}^{2+}$ and $\mathrm{Mg}^{2+}$-free Hanks medium) for $30 \mathrm{~min}$ at $38^{\circ} \mathrm{C}$. The trypsin digestion was arrested by trypsin inhibitor (Type II-S Soybean T-9128 Sigma; $2.5 \mathrm{mg} / \mathrm{ml}$ Hanks). After filtration and mechanical separation, the fibroblasts were cultured with DMEM supplemented with 15\% FCS (Gibco: 011-06290 M, batch 30F03205) on 6-well $\left(9.6 \mathrm{~cm}^{2}\right)$ plastic boxes coated with collagen I $\left(6 \mu \mathrm{g} / \mathrm{cm}^{2}\right)$. Fibroblasts in culture were $\gamma$-irradiated for 30 min (100 rads/ $\mathrm{min})$, trypsinized and reseeded at a cellular density of $105 / \mathrm{cm}^{2}$ on 4 -well $\left(1.9 \mathrm{~cm}^{2}\right)$ boxes. Irradiated or normal fibroblasts were stocked in 3-ml tubes after trypsinization and frozen in liquid nitrogen with $10 \%$ DMSO.

\section{Culture media}

The basal culture medium contained DMEM supplemented with $\beta$-mercaptoethanol $0.1 \mathrm{mM}$, $5 \%$ FCS, 5\% Ultroser G (IBF: 259501) and $10^{3}$ IU LIF (either natural of human origin: Soulillou, INSERM, Nantes; or recombinant murine LIF: ESGRO, Amrad, Australia). Cultures were performed at $38^{\circ} \mathrm{C}$ in a sterile incubator with controlled atmosphere (air $95 \%+\mathrm{CO}_{2} 5 \%$ ). The medium was changed every 2-3 d and colonies were gently trypsinized (Trypsin T1005 Sigma $0.25 \%$ in D-glucose $1 \%, \mathrm{Ca}$ - and $\mathrm{Mg}$-free Hanks medium) for 1-2 min.

To test whether some uterine factors were necessary for ES-like colonies in culture without a feeder monolayer, the culture medium was used as flushing medium for a G10-11 pregnant sow and after filtration, used as culture medium. Addition of different growth factors was performed to test their efficiency in promoting ES-like cell proliferation with or without feeders. The activity of recombinant human SCF (steel factor; Genzyme 1833-01; $10 \mathrm{ng} / \mathrm{ml}$ ) was tested after addition to the basal medium in culture without feeders. Different growth factors were added to the basal medium in culture with feeders: EGF (mouse, Sigma, E 4127: $10 \mathrm{ng} / \mathrm{ml}$ ), PDGF (human, Sigma, P 8147) and insulin (bovine, Sigma, I 5500) were added alone at the concentration of $4 \mathrm{ng} / \mathrm{ml}$ and $25 \mu \mathrm{g} / \mathrm{ml}$ respectively or in combination, PDGF $2 \mathrm{ng} / \mathrm{ml}+$ insulin $12.5 \mu \mathrm{g} / \mathrm{ml}$, respectively. TGF $\beta$ (human; Sigma,
T 1654) was used at the concentration of $0.3 \mathrm{ng} /$ $\mathrm{ml}$. Effects of growth factors were always compared to that of basal culture medium.

\section{Introduction of cells into nude mice}

Adult homozygous albino nude athymic mice (CSEAL, Orleans) were injected subcutaneously on the back either with porcine-irradiated fibroblasts $\left(10^{5}\right.$ cells in 1 male) or with porcine ESlike cells $\left(3 \times 10^{3}\right.$ cells/mouse). The first female received ES-like cells issuing from the 3 rd passage colonies of sow $A$; the second female received ES-like cells from the 4th passage colonies of sow B. They were killed $20 \mathrm{~d}$ later; skin and the different organs of the abdomen were fixed (ethanol $75 \%$; neutral formalin $20 \%$; pure acetic acid $5 \%$ ) and processed for analytical histology. Sections $(10-\mu \mathrm{m}$ thick) were stained with hematoxylin.

\section{RESULTS}

\section{Blastocyst development}

G5-6 embryos were found to be at the morula or blastocyst stages but most of the blastocysts were still enclosed in the zona pellucida. At the time of the blastocoele appearance, the inner cell mass consisted of 2-8 cells.

At G10-11 of gestation, the mean number of embryos per sow did not differ significantly between breeds (table I). Mei blastocysts were more homogeneous in size $(3.2 \mathrm{~mm}$; variation coefficient $=26 \%)$ as compared to the very heterogeneous LW (3.0 mm; 64\%) and WH (3.9 mm; 95\%) blastocysts. The diameter of the embryonic disc increased with that of the embryo $<3$ $\mathrm{mm}$ in diameter but was not correlated to the diameter of larger blastocysts. The number of cells in ED was $\approx 60-100$ in small embryonic discs $(50 \mu \mathrm{m})$ and 200 300 in larger ones $(200 \mu \mathrm{m})$. The embryon- 
Table I. Comparisons of Large White, Meishan and West hybrid embryos $(m \pm S D)$.

\begin{tabular}{|c|c|c|c|}
\hline & Large White & Meishan & West hybrid \\
\hline No sows & 14 & 9 & 16 \\
\hline Gestational age (d) & 11 & 10.5 & 10.5 \\
\hline $\begin{array}{l}\text { Sows a with elongated } \\
\text { blastocysts (\%) }\end{array}$ & 10 & 60 & 100 \\
\hline Corpora lutea & $16.1 \pm 12.7$ & $12.8 \pm 2.4$ & $18.2 \pm 1.6$ \\
\hline Embryo/sow & $12.3 \pm 3.7$ & $10.4 \pm 2.3$ & $13.3 \pm 4.6$ \\
\hline Embryo diameter $b$ & $3.0 \pm 1.9$ & $3.2 \pm 0.8$ & $3.9 \pm 3.7$ \\
\hline Dissected ED/sow ${ }^{c}$ & $11.3 \pm 3.8$ & $8.8 \pm 2.8$ & $8.4 \pm 7.2$ \\
\hline $\begin{array}{l}\text { Sows with attached ED d } \\
(\%, \mathrm{No})\end{array}$ & $77(7 / 9)$ & $100(6 / 6)$ & $46(7 / 15)$ \\
\hline $\begin{array}{l}\text { Sows with ES-like } \\
\text { colonies e }(\%, \mathrm{No})\end{array}$ & $55(5 / 9)$ & & $33(5 / 15)$ \\
\hline
\end{tabular}

a Elongation was analyzed at 10.5-10.8 d of gestation, Go being the day of insemination; ${ }^{b}$ apparent embryo diameter $(\mathrm{mm}) ;{ }^{\mathrm{c}}$ embryonic discs effectively dissected per sow; in small blastocysts, ED were not dissected; ${ }^{d}$ proportions of embryonic discs which attached to the feeder layers; ${ }^{e}$ proportions of sows in which at least one ED gave ES-like cell colonies which were reseeded at least 3 times; in Mei sows, ED cultures were performed without feeders.

ic discs originating from elongating or just elongated blastocyst differentiated within a few $d$, even when cultured on a feeder layer. The number of dissected ED, the proportion of dissected ED per total number of embryos (E) and the variation coefficient of ED collected (VC) were optimal in LW (ED $=11.3 ; E=92 \% ; V C=34 \%)$, intermediate in Mei $(E D=8.8 ; E=85 \%$; $\mathrm{VC}=32 \%)$ and poor in $\mathrm{WH}(\mathrm{ED}=8.4 ; \mathrm{E}=$ $63 \%$; VC $=86 \%$ ).

\section{Culture methods}

\section{Culture without feeders}

LW and Mei embryos were compared: ED from Mei sows attached rapidly with the greatest efficiency (6/6) but $50 \%$ (3/6) differentiated into embryoid bodies $1 \mathrm{wk}$ later; the longest duration of culture was 3 wk. In embryoid bodies, a great variety of cells (muscular, axon-like) was obtained; the spontaneous phenomenon of "beating heart" and in some cases, cells with the morphological appearance and the alkaline phosphatase reactivity of primordial germ cells were obtained. The longest duration of ED cells in culture was 3 wk. Embryonic discs originating from LW sows attached rapidly (5/6) and the ES-like cells were maintained without differentiation $(4 / 6)$ for $\approx 6 \mathrm{wk}$. The ED cells formed monolayered colonies of numerous $(>100)$ epithelioid small cells presenting a large nucleus with 1 or 2 prominent nucleoli (fig 1b). 


\section{Culture on feeder layer}

\section{Embryonic discs dissected from G10-11 blastocysts}

Blastocysts from LW and WH sows were compared. The proportion of sows in which ED attached was $77 \%$ in LW and only $46 \%$ in WH and the proportion of sows with formation of colonies reseeded at least 3 times was $55 \%$ and $33 \%$ in LW and $\mathrm{WH}$ respectively. The ED cells formed multilayered colonies of small cells in which the cytoplasmic limits were hardly visible; the nuclei with one very small nucleolus were round and very small; the colonies were generally well delineated and the feeder cells surrounding the colonies were more elongated than those free of ES-like cells (fig 1c). The longest duration of culture of ES-like cells was 3 months, corresponding to 11 passages without differentiation for LW blastocysts. Embryoid bodies appeared often after only 3 or 4 passages of ES-like cells, more abundant in WH than in LW embryos.

\section{G5-6 blastocysts cultured in toto}

From the $8 \mathrm{WH}$ sows used, $37 \%$ (3/8) gave rise to attached embryonic discs but only $13 \%(1 / 8)$ gave small colonies of ESlike cells accompanied by large cells apparently of endoderm nature. Some of these ES-like cells have been reseeded 3 times.

\section{Effects of growth factors}

\section{Cultures without feeders}

The use of flushing medium as culture medium hightened attachment of the dissected ED but also resulted in their rapid differentiation. The addition of SCF to the basal medium prevented the attachment of ED to the plastic.

\section{Culture on feeder monolayer (table II)}

Addition of EGF did not modify the attachment of embryonic discs or the growth of ES-like colonies. In embryos of $2 \mathrm{WH}$ sows (G5: 7 blastocysts in zona pellucida +5 morula; G6: 16 hatched blastocysts) cultures with or without TGF $\beta(0.3 \mathrm{ng} / \mathrm{ml})$ for 3 wk did not modify ED attachment, formation or proliferation of ES-like cell colonies.

Thirty-six embryonic discs originating from $3 \mathrm{WH}$ G10 sows and 10 G6 blastocysts were used to compare the effects of adding insulin, PDGF or insulin + PDGF to the culture medium; PDGF alone increased the size of the colonies during the first 2 weeks; however this effect was transitory and later on subsequently differentiated cells appeared. Insulin alone had a small transitory effect. With PDGF + insulin, more small colonies formed by small ES-like cells were obtained while in control medium embryonic discs of the same animals gave rise to embryoid bodies.

\section{Injection of cells in nude mice}

Twenty $d$ after injection of cells no obvious difference was visible on living mice 1 and 2 but after dissection, both presented nodules under the skin. In the mouse 2, in addition to the previous observations, an overgrowth of the last asternal floating ribs was obtained. In the control mouse that had received the irradiated fibroblasts no obvious difference was observed. The histological analysis of ES-like receiving mice at the site of cell injection, revealed the presence of teratomas delineated by fibroblasts layers. In these nodules, abnormal cartilage mixed with blood cells and hematopoietic tissue were surrounded by muscles and epithelia (fig 1d). In the mouse which had received the irradiated fibroblasts, the histological appearance of the 
Table II. Effects of growth factors on ES-like cells cultured in vitro.

\begin{tabular}{lcccc}
\hline Factors & Concentration $(\mathrm{ml})$ & Attachment & Proliferation & Differentiation \\
\hline Without feeders & & & & \\
LIF & $10^{3} \mathrm{IU}$ & 0 & 0 & - \\
Uterine flushing & $1 \mathrm{ml}$ & + & + & ++ \\
SCF & $20-30 \mathrm{ng}$ & - & 0 & 0 \\
With feeders & & & & \\
EGF & $10 \mathrm{ng}$ & 0 & 0 & 0 \\
Insulin & $5 \mu \mathrm{g}$ & 0 & 0 & 0 \\
PDGF & $25 \mu \mathrm{ng}$ & 0 & + & 0 \\
Insulin + PDGF & $42.5 \mu \mathrm{g} / 2 \mathrm{ng}$ & 0 & + & 0 \\
TGF $\beta$ & $0.3 \mathrm{ng}$ & 0 & + & 0 \\
& & 0 & 0 & 0 \\
\hline
\end{tabular}

0 : no modification; +: increased attachment, proliferation or differentiation; -: decreased attachment, proliferation or differentiation.

skin and tissues revealed no teratoma but a spontaneous lymphoma was observed in intestinal wall.

\section{DISCUSSION AND CONCLUSION}

In this study, we have shown porcine breed differences in the ability to obtain homogeneous batches of blastocysts and in the feasibility of embryonic disc isolation. Among these breeds, the best results were obtained from LW where the embryo developed slowly as compared with Mei but with a better homogeneity than that of $\mathrm{WH}$. In this latter breed, the blastocyst size and development were highly variable between sows and between embryos of the same sow. The reproductive performances obtained for Meishan and Large White breeds correspond to those observed by Bazer et al (1988) and the French Meishan gilts had a lower ovulation rate than those used by Ashworth et al (1992). The num- ber of embryonic disc cells observed in young G10 blastocysts were much lower than those counted by Barends et al (1989). In the same breed, WH, the G1011 blastocysts were better donors of embryonic disc and ES-like colonies than the G5-6 ones. Strojek et al (1990) obtained more ES-like cells from D10 porcine blastocysts cultured in toto than from D9 blastocysts. Furthermore, microsurgical dissection of G10-11 embryonic discs prevented their differentiation under the possible effect of primitive endoderm and their invasion to trophectoderm cells which are flattened in vitro and actively multiplying. A similar technique of dissection of the embryonic disc was previously applied by Notarianni et al (1990) and by MeineckeTillmann and Meinecke (1991), while Piedrahita et al (1990) and Chen et al (1991) preferred immunosurgery. When cultured directly on plastic coated with collagen I, the dissected porcine embryonic disc forms a monolayer of epithelioid cells even 
in the presence of natural human or recombinant murine LIF. In contrast when cultured on feeder layers of foetal porcine fibroblasts, they maintain a multilayered structure, an undifferentiated morphological appearance and a better proliferative activity. The absence of LIF in ED cultured on plastic induces rapid differentiation, and the presence of LIF alone does not allow a long duration of culture nor prevent a small differentiation of ED cells into epithelioid cells.

Different growth factors have been tried to stimulate the growth of blastocysts or embryonic discs in vitro. We have observed a better growth after combination of PDGF, insulin and feeder cells; however all the cultures were performed with $5 \%$ foetal calf serum and $5 \%$ Ultroser $\mathrm{G}$ which contain growth factors. IGF1 is believed to increase protein synthesis in embryonic discs cultured in vitro (Estrada et al, 1991). Strojek et al (1990) stimulated multiplication of ES-like cells in vitro with a high dose of insulin $(0.2 \mathrm{mg} / \mathrm{ml})$. MessengerRNA for EGF receptors was found to be continuously present in the pig conceptus before implantation but EGF seemed to act preferentially after elongation (Vaughan et al, 1992).

The presence of embryoid bodies giving rise to differentiated cells indicates that the colonies obtained were at least pluripotent. The same conclusion could be drawn from the injections of ES-like cells in nude mice; they induced teratoma corresponding to the primitive cellular lineages of the porcine embryo, while with irradiated fibroblasts alone, no teratoma were obtained. Teratoma deriving from ES-like cells were found only in the vicinicity of the injection point on the back, in the dermal muscle layers. They were delineated by a layer of fibroblasts.

In conclusion, the dissection of embryonic discs before elongation of pig blas- tocysts, the elimination of primitive endoderm and trophectoderm and the culture of ED on irradiated foetal fibroblasts each contribute to the ability of ED to form colonies of porcine ES-like cells. Their ability to give rise to teratocarcinomas when injected into nude mice suggest that they are at least pluripotent.

\section{ACKNOWLEDGMENTS}

This work was supported by grants from the Ministère de la Recherche et de l'Espace and from the Action Incitative sur Programme: Transgenèse, INRA. We thank JP Soulillou for donating the human LIF. We thank the pig breeding staff at Nouzilly and Rouille for care of the animals, $A$ Moens and $H$ Salmon for aid with the feeder preparation, $M$ Courot for his constant assistance throughout this study and preparation of the manuscript, and $\mathrm{R}$ Porter for his assistance with the translation.

\section{REFERENCES}

Ashworth CJ, Haley CS, Wilmut I (1992) Effect of regumate on ovulation rate, embryo survival and conceptus growth in Meishan and Landrace $x$ Large White gilts. Theriogenology 37, 433-443

Barends PMG, Stroband HWJ, Taverne N, te Kronnie G, Leën MPJM, Blommers PCJ (1989) Integrity of the preimplantation pig blastocyst during expansion and loss of polar trophectoderm (Rauber cells) and the morphology of the embryoblast as an indicator for developmental stage. J Reprod Fertil 87 , 715-726

Bazer FW, Thatcher WW, Martinat-Botté F, Terqui M (1988) Conceptus development in Large White and prolific Chinese Meishan pigs. J Reprod Fertil 84, 37-42

Chen LR, Wang JP, Wu MC (1991) In vitro culture of mammalian embryonic stem cells: II. In vitro culture of blastocyst-derived cells in mouse and pig. J Chinese Soc Anm Sci 20 , 327-339 
Estrada JL, Jones EE, Johnson BH, Petters RM (1991) Effect of insulin-like growth factor I on protein synthesis in porcine embryonic discs cultured in vitro. J Reprod Fertil 93, 53-61

Evans MJ, Kaufman MH (1981) Establishment in culture of pluripotential cells from mouse embryos. Nature (Lond) 292, 154-156

Lallemand $Y$, Brulet $P$ (1990) An in situ assessment of the routes and extent of colonisation of the mouse embryo by embryonic stem cells and their descendants. Development 110, 1241-1248

Martin GR (1981) Isolation of a pluripotential cell line from early mouse embryos cultured in medium conditioned with teratocarcinoma cells. Proc Natl Acad Sci USA 78, 7634-7639

Meinecke-Tillmann S, Meinecke B (1991) Experiments on the establishment in culture of pluripotential cell lines from sheep, goat and pig embryos. In: 7th Sci Meet AETE. Cambridge, 14-15/09/1991

Notarianni E, Laurie S, Moor RM, Evans MJ (1990) Maintenance and differentiation in culture of pluripotential embryonic cell lines from pig blastocysts. J Reprod Fertil (suppl) 41, 51-56

Piedrahita JA, Anderson GB, BonDurant $\mathrm{RH}$ (1990) On the isolation of embryonic stem cells: comparative behavior of murine, porcine and ovine embryos. Theriogenology 34 , 879-901

Strojek RM, Reed MA, Hoover JL, Wagner TE (1990) A method for cultivating morphologically undifferentiated embryonic stem cells from porcine blastocysts. Theriogenology 33, 910-913

Vaughan TJ, James PS, Pascall JC, Brown K (1992) Expression of the genes for TGF, EGF and EGF receptor during early pig development. Development 116, 663-669

Wilmut I, Hooper ML, Simons JP (1991) Genetic manipulation of mammals and its application in reproductive biology. J Reprod Fertil 92, 245-279

Yang X, Anderson GB (1992) Micromanipulation of mammalian embryos: principles, progress and future possibilities. Theriogenology 38 , 315-335 